\title{
IMPORTANCE OF THE ENVIRONMENT IN INDONESIAN LEARNING
}

\author{
Kartika Kencana/19016166 \\ kencanakartika32@gmail.com
}

The environment is a medium in which living things live, survive, and have distinctive characters and functions that are reciprocally related to the existence of living things that occupy them, especially humans who have more complex roles. Ira et al (2018) say that between humans and their environment there is a reciprocal relationship. Humans affect their environment, and vice versa humans are influenced by their environment and are inseparable from each other. This is because the influence of the environment is very large on everyone's life. Various kinds of things can be found in the environment, ranging from learning to problems. According to Sukma (2020) as individuals, humans have a responsibility to solve environmental problems. One form of effort to overcome these environmental problems is with the correct knowledge of all environmental factors to protect the environment, and all of that can be obtained through the educational process.

According to Oemar Hamalik (2004: 195) the environment as the basis of teaching is a conditional factor that affects individual behavior and is an important learning factor. So that the use of the environment can be used as a medium in learning methods. Putri et al (2019) revealed that in learning in a school environment, teaching reading must receive serious attention from educators in Indonesia. Through teaching, educators are able to direct students in language learning. According to Uyar and Ensar (in Ramadhan et al, 2019) using environmental themes in text learning can trigger students' interest in learning languages and by implication can increase students' knowledge about the environment.

Ramadhan et al (2019) say that environmental education is important to increase students' attitudes and awareness of the environment. Ramadhan et al (2019) also stated that environmental education is able to help students rethink the relationship or correlation between humans and their environment. With this environment-based learning, students will be more sensitive to environmental conditions. The environment is a very influential component in carrying out teaching and learning activities, especially in learning Indonesian. Learning Indonesian in class sometimes makes students feel bored, it can even lead to decreased student motivation. Zulhafizh et al (2013) say that if students' attitudes and learning motivation towards Indonesian language lessons are low, it is necessary to develop and improve students' attitudes and learning motivation towards Indonesian language lessons. Therefore, when students experience a decrease in learning motivation, teachers can invite students to take advantage of the environment as a fun learning medium. Not only students, teachers also need to think creatively in utilizing the environment to be used as learning media. Teachers are facilitators for their students. This is in line with the statements of Sukma (2012) and Ramadhan et al (2019), namely the teacher functions as a facilitator and learning manager in the learning process. 
Learning carried out in the environment will improve students' creative thinking skills, so that students can develop various kinds of written works. Atmazaki (in Wilda et al, 2014) explains that creative thinking skills are needed in appreciating literary works because literature itself is a creative work. According to Semi (in Ira et al, 2018) that writing is a creative process, it must experience a process that is consciously passed and consciously also seen the relationship with one another, so that it ends in a clear goal. Munandar (in Piliang et al, 2014) states that creativity is the result of an individual's interaction with his environment, it is clear that individual creativity is largely determined by encouragement or motivation from within and his environment. The things that have been mentioned before will later relate and affect student learning outcomes.

According to Ramadhan et al (2018), innovative learning models can improve student learning outcomes. The process of learning Indonesian in the environment is one way to develop student innovation by collaborating with the environment around them. Therefore, the learning process in the environment can be applied in Indonesian language learning. Ramadhan et al (2019) revealed that the use of environmental themes in text-based learning can trigger students' interest in learning languages and can implicitly increase students' knowledge about the environment.

Based on the questionnaire that the author distributed about "The Importance of the Environment in Indonesian Language Learning" to members of the TNI, Polri, Padang State University students, Andalas University students, STKIP PGRI students, STAI YAPTIP students, Padang Pharmacy Stikes students, Syedza Saintika Stikes students, Syiah University students Kuala. From a total of 32 respondents who participated in filling out the questionnaire, 25 were more dominant female respondents and 7 male respondents with a percentage of $78.1 \%$ female, $21.9 \%$ male. The results of the data from the percentage of questionnaires that have been carried out through the google form can be seen as follows.

The first question, "providing environmental material in Indonesian language learning in the form of narrative text is an effort to build ecological intelligence" $46.9 \%$ strongly agree, $53.1 \%$ agree, $0 \%$ disagree, and $0 \%$ disagree. The second question, "developing a literary work by observing the surrounding environment" 59.4\% stated strongly agree, $40.6 \%$ agreed, $0 \%$ disagreed, and $0 \%$ disagreed. The third question, "make the environment an inspiration in developing a literary work" 59.4\% stated strongly agree, $40.6 \%$ agreed, $0 \%$ disagreed, and $0 \%$ disagreed. The fourth question, "can develop a poem by observing the surrounding environment" $43.8 \%$ strongly agree, $53.1 \%$ agree, $3.1 \%$ disagree, and $0 \%$ disagree. The fifth question, "observing unique objects to get interesting things in making short stories" $59.4 \%$ strongly agree, $37.5 \%$ agree, $3.1 \%$ disagree, and $0 \%$ disagree. The sixth question, "all literary works of 'folklore' describe the social life of the community" $59.4 \%$ stated strongly agree, $28.1 \%$ agreed, $12.5 \%$ disagreed, and $0 \%$ disagreed. The seventh question, "Timun Mas" folklore related to the environment in Indonesian language books" $34.4 \%$ strongly agree, $56.3 \%$ agree, $9.4 \%$ disagree, and $0 \%$ disagree. The eighth question, "the environment can directly or indirectly develop a mindset, act. behave physically and mentally in daily life" $65.6 \%$ stated strongly agree, $31.3 \%$ agreed, $3.1 \%$ disagreed, and $0 \%$ disagreed. The ninth 
question, "the environment in Indonesian language learning can be applied in everyday life" $53.1 \%$ strongly agree, $46.9 \%$ agree, $0 \%$ disagree, and $0 \%$ disagree. The tenth question, "environment is very important in learning Indonesian" $65.6 \%$ strongly agree, $34.4 \%$ agree, $0 \%$ disagree, and $0 \%$ disagree.

From the results of the questionnaires that have been carried out, the authors can conclude that the environment has a relationship with learning Indonesian. This is evidenced by respondents consisting of students and the general public, who consider that the environment is an important thing and has a relationship in learning Indonesian. According to the author, people's understanding of the relationship between the environment and learning Indonesian is categorized as good. Thus, the environment will help students improve their creative and logical thinking in learning Indonesian. 


\section{REFERENCES}

Ira Guci, R Syahrul, Nursaid Nursaid. (2018). The Correlation of Vocabulary Mastery in the Environmental Sector By Writing Argumentative Essays About the Environment. Journal of Indonesian Language and Literature Education, Vol. 5 No. 2 September 2016; $\quad$ Series B 169-174.

Piliang, Wilda S. H., Atmazaki, and Syahrul Ramadhan. (2014). The Contribution of Literary Appreciation and Creative Thinking Skills to Dramatic Playing Skills in Class XII Social Studies Students of SMA Negeri 2 Rengat, Indragiri Hulu Regency. Journal of Language, Literature and Learning, 2(2), 75-87.

Putri, Diana and Syahrul R. (2019). Correlation of Reading Comprehension Skills and Text Writing Skills on Observation Results of Class VII Students of SMP Negeri 4 Pariaman. Journal of Indonesian Language and Literature Education, 8(1), series A 62-69.

Ramadhan, S., Elfia Sukma, and Vivi Indriyani. (2019). Environmental Education and Disaster Mitigation Through Language Learning. IOP Conference Series: Earth and Environmental Science, 314, p. 1-9.

Ramadhan, S., Elfia Sukma, and Vivi Indriyani. (2019). Teacher's Perception of the Use of Indonesian Language Teaching Materials with Mobile Devices and Edmodo Applications. Language Examination International Seminar.

Ramadhan, S., Yasnur Asri, and Vivi Indriyani. (2018). Learning Module Design Writing Argumentative Text Based Problem-Based Learning. Advances in Social Science, Education and Humanities Research, Vol 263: 194-200.

Sukma, Elfia. (2012). Competency-Based Integrative Literature Learning. International Conference on Languages and Arts, Pages 432-436.

Sukma E, and VP Azrianti. (2020). Instilling Positive Characters in Students Using Folker in the Macromedia Application. Advances in Social Science, Education and Humanities Research, Volume 485.

Oemar Hamalik. (2004). Teaching and learning process. Jakarta: Earth Literacy.

Wilda Srihastuty Handayani Piliang, Atmazaki, Syahrul R. (2014). The Contribution of Literary Appreciation and Creative Thinking Skills to Dramatic Playing Skills in Class XII Social Studies Students of SMA Negeri 2 Rengat, Indragiri Hulu Regency. Journal of Language, Literature and Learning, Vol. 2 No. 2, June 2014. 
Zulhafizh, Atmazaki, Syahrul R. (2013). The Contribution of Students' Attitudes and Learning Motivation to Indonesian Language Learning Outcomes. Journal of Language, Literature and Learning, Vol. 1 No. 2, June 2013. 